Reports

$2-2002$

Settlement and survival of the oyster Crassostrea virginica on created oyster reef habitats in Chesapeake Bay

Janet A. Nestlerode

Mark W. Luckenbach

Robert J. Diaz

Follow this and additional works at: https://scholarworks.wm.edu/reports

Part of the Aquaculture and Fisheries Commons 


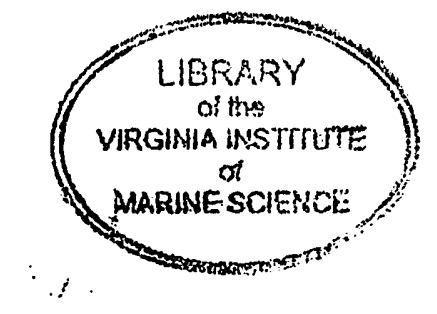

\title{
Settlement and survival of the oyster Crassostrea virginica on created oyster reef habitats in Chesapeake Bay
}

\author{
Janet A. Nestlerode \\ School of Marine Science \\ Virginia Institute of Marine Science \\ Gloucester Point, VA 23062 \\ Phone: (804) 684-7694 \\ Internet: janetn@vims.edu \\ Dr. Mark W. Luckenbach \\ Professor of Marine Science / Co-Graduate Advisor \\ Virginia Institute of Marine Science \\ Eastern Shore Laboratory \\ College of William and Mary \\ Wachapreague, VA 23480 \\ Phone: (757) 787-5834 \\ Internet: luck@vims.edu \\ Dr. Robert J. Diaz \\ Professor of Marine Science / Co-Graduate Advisor \\ Virginia Institute of Marine Science \\ College of William and Mary \\ Gloucester Point, VA 23062 \\ Phone: (804) 684-7364 \\ Internet:diaz@vims.edu
}

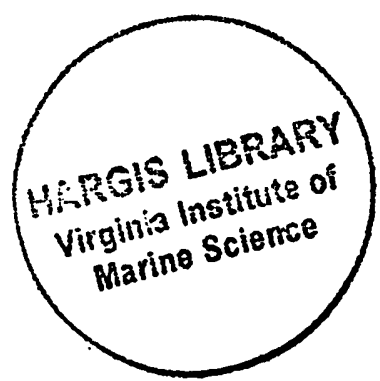

Final Report on research conducted in the Goodwin Islands (Virginia) CBNERR VA Site

Submitted February 2002

NOAA Award No. NA970R0147 


\section{TABLE OF CONTENTS}

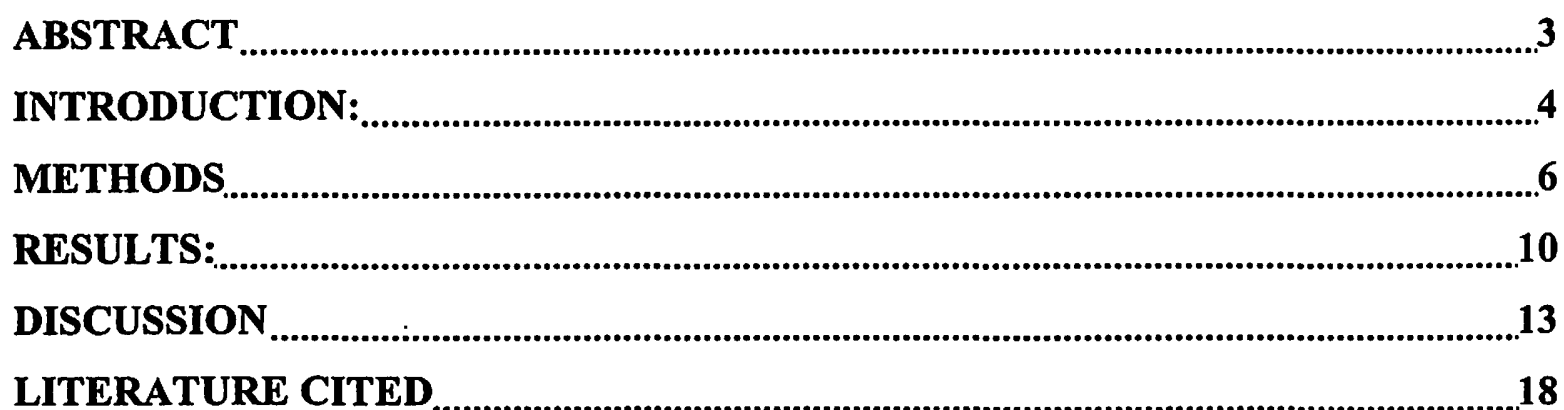

FIGURES AND TABLES

Figure 1. Study sites.....................................................................................................22

Figure 2. Density of small $(\leq 30 \mathrm{~mm})$ oysters on Goodwin Island Reef....................23

Figure 3. Density of large $(>30 \mathrm{~mm})$ oysters on Goodwin Island Reef.....................24

Figure 4. Size frequency of oysters on Goodwin Island Reef......................................25

Figure 5. Proportion of dead oysters with evidence of decapod predation.................26

Figure 6. Patterns of surf clam shell fragments size distribution on reef....................26

Figure 7. Density of oysters on reefs, Fisherman's Island, VA ...................................27

Figure 8. Size frequency of oysters on Fisherman's Island Reef................................28

Table 1(a). Summary of ANOVA of oyster densities on Goodwin Island reef........29

Table 1(b). Results of SNK tests .....................................................................30

Table 2. Summary of ANOVA of oyster densities on Fisherman's Is reef.................30

ACKNOWLEDGEMENTS ............................................................................................ 


\begin{abstract}
Efforts to restore Crassostrea virginica oyster reef habitats in Chesapeake Bay typically begin with the placement of hard substrata, such as oyster shell, in the form of threedimensional mounds on the seabed to serve as a base for oyster recruitment and growth. A shortage of sufficient volumes of oyster shell for creating large-scale reefs has led to widespread use of other materials, such as surf clam (Spisula solidissima) shell, as a substitute for oyster shell. We monitored oyster recruitment, survival, and growth on intertidal and subtidal reefs constructed shucked oyster and surf clam shell. Results indicate that oyster settlement occurred on both substrate types throughout the monitoring period but high levels of postsettlement mortality occurred on clam shell mounds. On the subtidal clam shell mound, the quality of the substrate material varied with reef elevation with large shell fragments and intact valves scattered around the reef base and small, tightly packed shell fragments paving the crest and flank of the reef mound. The abundance of oysters on this reef reflected this distribution where oysters were more abundant and larger at the reef base and less abundant and smaller on the crest of the reef. Oyster shell reefs supported greater oyster growth and survival and offered the highest degree of structural complexity. We suggest that the availability of interstitial space and appropriate settlement surfaces account for the observed differences in oyster abundance across the reef systems. The patterns observed give context to the importance of substrate selection in similar restoration activities.
\end{abstract}

Key Words: oyster reefs, habitat restoration, recruitment substrate, oyster stocks, Virginia, Chesapeake Bay, intertidal, subtidal 


\section{INTRODUCTION:}

Oyster reefs serve an ecologically important role by providing the predominate natural hard substrate in the characteristically sedimentary environment of the middle Atlantic coastal plain. The three-dimensional structure of oyster reef habitat created by Eastern oyster (Crassostrea virginica) imparts vast amounts of surface area for attachment and crevices for refuge for newly settled oysters, as well as numerous small invertebrates and fishes (Wells 1961; Bahr 1974; Dame 1979; Zimmerman et al. 1989). Oyster reefs, which were once a prominent feature in the Chesapeake Bay ecosystem before European colonization and intense overharvesting during the 19th and 20th centuries, have been reduced to mere footprints of their original upthrusting profile (Hargis 1999). Years of poor resource management of both live oysters and shell, mortality from diseases caused by the protistan parasites Perkinsis marinus ("Dermo") and Haplosporidium nelsoni ("MSX"), and increased sedimentation and environmental degradation have all contributed to a dramatic decline in oyster populations in Chesapeake Bay. These natural, self-renewing habitats have been effectively destroyed and are the focus of many habitat restoration efforts throughout the Chesapeake Bay system (Kennedy and Sanford 1999; O’Beirn et al. 2000; reviewed by MacKenzie 1996 and Mann 2000).

Efforts to restore oyster reef habitats typically begin with the placement of hard substrata on the seabed to serve as a base for oyster recruitment and growth. Numerous studies have emphasized the importance of vertical relief of these created habitats on oyster growth and survival in altering water flow and sedimentation (Lenihan 1999), and in elevating the habitat into the intertidal zone (Bartol and Mann 1999; O'Beirn et al. 2000; Volety et al. 2000). Since the early 1990's, reefs in lower Chesapeake Bay have been commonly built as three-dimensional mounds ranging in height from approximately 0.5 to $2 \mathrm{~m}$ above the seabed (Wesson et al. 1999; O'Beirn et al. 2000). While many of these created reefs in lower Chesapeake Bay reach into the intertidal zone, some are located in deep regions or have settled or eroded and are entirely subtidal. Whether intertidal or subtidal, the structure of these hummocks should offer adequate surface and interstitial heterogeneity for oyster growth and survival and for recruitment by other 
epifaunal species. Bartol et al. (1999) underscore the importance of interstitial space within the fabric of intertidal reefs to promote oyster survival during periods of severe solar exposure and predation. The material used to create oyster reefs should afford this interstitial heterogeneity. The most common substrate material used in oyster reef restoration efforts is Crassostrea virginica shell which, when piled into mounds, is generally resistant to erosion to maintain structure of the hummocks and forms an adequate interstitial matrix of void spaces between the shell pieces. These spaces provide refugia from predation and moderation of physical stress for oysters and associated reef fauna. Shortages of oyster shell in some regions have prompted a search for alternative substrates for reef construction.

One material commonly used as an alternative to oyster shell is shucked surf clam (Spisula solidissima) shell. With repeated handling associated with large-scale reef construction, $S$. solidissima shells fracture into small pieces that pack tightly together and thus provide very limited interstitial space for occupation by oysters and colonizing reef fauna. Overall interstitial volume afforded by fractured $S$. solidissima shell is significantly less than that provided by oyster shell (O'Beirn et al. 2000). To date, only O'Beirn et al (2000) have examined the efficacy of the shucked S. solidissima shell substrate in large-scale intertidal reef restoration efforts but similar details have not been quantified for clam shell reefs in subtidal habitats.

The objective of this project is to examine and contrast the oyster recruitment, growth, and survival on a subtidal Spissula solidissima shell constructed reef in lower York River and intertidal reefs constructed of Crassostrea virginica shell and $S$. solidissima shell near the mouth of Chesapeake Bay at Fisherman's Island. The results have relevance for the selection and placement of materials and of design strategies for oyster reef restoration. 


\section{METHODS}

\section{Site Description}

Our study area included two created oyster reef sites protected from commercial harvesting in lower Chesapeake Bay. One site was situated at the mouth of the York River approximately $1 \mathrm{~km}$ north of Goodwin Island (a Chesapeake Bay National Estuarine Research Reserve in Virginia site, Figure 1). In spring 1995, the Virginia Marine Resources Commission (VMRC) Shell Replenishment Program and Amoco Oil Company (Yorktown, Virginia) constructed an oyster reef base of crushed surf clam (Spisula solidissima) shell on a subtidal sandflat (Meisner 1995). The subtidal artificial reef habitat at Goodwin Island is constructed of 30,000 bushels $\left(1057 \mathrm{~m}^{3}\right)$ of shucked $S$. solidissima shell. The reef measures approximately $1350 \mathrm{~m}^{2}$ and mounds approximately $2 \mathrm{~m}$ above a seabed that is $3 \mathrm{~m}$ deep at MLW. Prior to this project, there has been no evaluation of the communities associated with the Goodwin Island reef since its construction.

The other created oyster reef site is located at the Fisherman's Island National Wildlife Refuge near the mouth of Chesapeake Bay at Virginia's eastern shore. During summer 1996, eleven intertidal oyster reef habitats were constructed of three substrate materials: Crassostrea virginica shell, Spisula solidissima shell, and pelletized coal ash (Figure 1). The reefs range in size from 162 to $364 \mathrm{~m}^{2}$ and each is considerably smaller than the reef at Goodwin Island (O'Beirn et al. 2000). Although the Fisherman's Island and Goodwin Island reef systems are characterized by different physical (salinity, tidal range, intertidal vs. subtidal reefs, etc.) and biological (benthic and nektonic community species composition, nutrient regimes, etc.) regimes, this study offers an opportunity to evaluate the use of alternative substrates in oyster reef restoration efforts by comparing the efficacy of using $S$. solidissima shells as reef bases under distinctly different conditions. Both sites are designated as research sanctuaries and commercial and recreational harvesting of oysters 


\section{Oyster Sampling:}

Sampling of the reef to determine oyster abundance and size at Goodwin Island took place from Fall 1999 through Summer 2001. Using reference stakes permanently positioned at the reef margins, the surface of the reef was divided into a grid and coordinates were assigned to each cell of the grid. The reef was further subdivided into three depth strata - crest ( $1.5 \mathrm{~m}$ above the seabed), flank ( $0.8 \mathrm{~m}$ above the seabed), and base ( $0.2 \mathrm{~m}$ above the seabed). Within each depth strata, the coordinates on the reef surface were selected randomly without replacement for each sample (once a cell was sampled, the coordinate of the area was be recorded so that sampled areas were excluded from selection at a later date). Within the cell, divers placed a square plastic frame $(0.25$ $\mathrm{m} \times 0.25 \mathrm{~m}$ ) on the reef surface and all substrate material within the frame was removed by hand to a depth of $10 \mathrm{~cm}$ (below this depth, shell and associated sediments were dark black in color and indicative of anoxic conditions) and placed in a cloth bag. Samples were transported to the laboratory in ice chests and stored in flow-through seawater tanks until processing. Samples were elutriated within 48 hours of collection over a $500 \mu \mathrm{m}$ mesh screen. Six replicate quadrat samples per sampling period were collected from each elevation strata. All live adult (oysters $>30 \mathrm{~mm}$ shell height), juveniles ( $\leq 30 \mathrm{~mm}$ shell height) and recently dead (with empty, paired, articulated valves with no evidence of interior fouling) oysters were counted and measured.

Similar methods were used at Fisherman's Island for assessing oyster stocks on the created intertidal reefs (described in detail in O'Beirn et al. 2000). Briefly, in May 1997,1998 , and 1999 , three $0.0625 \mathrm{~m}^{2}$ quadrats were collected from each of three tidal elevations on two replicate reefs of each substrate type for a total of 18 quadrates per substrate type per sampling event. The elevations were subtidal ( 0.25 below mean low water), at mean low water, and intertidal ( $0.25 \mathrm{~m}$ above mean low water). All live and recently dead (with paired, articulated valves with no interior fouling) oysters were enumerated and measured to the nearest $0.1 \mathrm{~mm}$.

\section{Oyster Disease:}

A sample of 25 oysters pooled from all elevation strata were collected from the Goodwin Island reef in November 1999 and analyzed for Haplosporidium nelsoni and 
Perkinsus marinus infections. Oysters were examined for the presence of $P$. marinus using Ray's fluid thioglycollate medium technique (Ray 1952). The intensity of infection was estimated on a semi-quantitative scale (Mackin 1962) in which $0=$ no infection, $1=$ very light, $2=$ light, $3=$ light to moderate, $4=$ moderate, $5=$ moderate to heavy, $6=$ heavy. Weighted prevalences were determined by adding the individual assigned intensities and dividing by the number of oysters sampled (Mackin 1962).

Haplosporidium nelsoni infections were detected using a histological analysis of paraffin-embedded tissue stained with hematoxylin and eosin. The scale of Burreson et al. (1988) was used to describe infection intensities and prevalences where $0=$ no infection, 1 = cells were rare, 2 = fewer than 2 cells per field of view ( $40 \mathrm{x}$ objective) (light), $3=$ two to five cells per field of view (moderate), $4=$ more than five cells per field of view (heavy).

\section{$\underline{\text { Statistical analysis }}$}

Differences in oyster densities among reef elevations (base, flank, crest) and among sampling times (November 1999, July 2000, June 2001) at the Goodwin Island reef were assessed by two-way full-factor fixed effects model ANOVA. Separate ANOVA's were conducted for small $(\leq 30 \mathrm{~cm}$ shell height) and large $(>30 \mathrm{~cm}$ shell height) live oysters and for identical categories of dead oysters to independently examine the effects of elevation and date on survival of young-of-year and mature oysters. Cochran's test was used to test for homoscedasticity of variances. Density values were $\log$ transformed $[\ln (x+1)]$ to conform to homogeneity and normality assumptions. Student-Newman-Keuls a posteriori tests were used to explore differences among means when significant factor and interactive effects were detected (Underwood 1997; pp. 331335).

The reefs at Fisherman's Island were not compared statistically with the Goodwin Island reef because of the confounding effects of temporal difference in reef construction and considerable dissimilarities in reef surface area and tidal and salinity regime exposure. Because of settling and erosion of the reefs over time (in particular, one of the oyster shell reefs), we were unable to sample the higher tidal heights from all reefs during the entire study. Therefore, for the purpose of comparing oyster density by reef substrate 
type, we restricted our analysis to the samples collected from the subtidal and mean low water reef elevations. Differences in live oyster densities among reef elevations, substrate types, and sampling times at the Fisherman's Island reefs were assessed with separate three-way ANOVA models with year, reef type, and elevation as factors. Heteroscedastic variances were corrected with a $\ln (x+1)$ transformation. 


\section{RESULTS:}

Oyster densities on the Goodwin Island reef show a clear pattern in oyster abundance relative to reef elevation at all sampling times with the base of the reef exhibiting greater oyster densities than reef crest (Figures 2 and 3). Two-way ANOVA revealed that only elevation on the reef influenced densities of both live and dead larger oysters ( $>30 \mathrm{~mm}$ ) (Table 1a). These oysters were significantly more abundant at the reef base compared with the flank and crest. Densities of smaller live oysters $(\leq 30 \mathrm{~mm})$ were significantly affected by elevation, date, and their interaction $(P=0.007)$. SNK tests performed to decouple the cause of the elevation $x$ date interaction revealed: (1) during the 1999 and 2000 sampling events densities of small live oysters were greater at the flank and base than densities at the crest; (2) during the 2001 sampling period no difference in small oyster density according to reef elevation was detected; (3) recruitment of small oysters was lowest in 2000 across all elevations. Densities were greatest in 1999 and intermediate in 2001 at both the reef flank and base, but no significant differences were detected in densities these years at the reef crest (Table 1b). Densities of small dead oysters ( $\leq 30 \mathrm{~mm}$ ) were significantly affected by elevation and date. These oysters were significantly more abundant at the reef base than at the flank and crest (Table 1a).

Mean oyster densities for each size class from each reef elevation are reported in size frequency distributions (Figure 4). For all three years, young-of-the-year animals ( $\leq$ $30 \mathrm{~mm}$ ) numerically dominated all of the samples. A unimodal population distribution of these small oysters is apparent at the reef crest each year. The other reef strata exhibit bimodal oyster size distributions with smaller oysters dominating throughout and larger oysters (>30 mm) rare. A greater proportion (albeit small) of larger oysters were collected from the reef base than from the reef flank. Dead oysters (with articulated shells) were present at each elevation each year and, although fewer in number, tended to reflect the distribution of live oysters at each elevation.

Dead oysters were examined for evidence of predation by crabs in 2000 and 2001. Predation by crabs on oysters was distinguished from other sources of mortality by the presence of chipped or cracked valve margins, puncture holes within the umbo region, 
crushing of the umbo region, and complete crushing of the valves. Dead oysters with such characteristics were collected from each reef elevation, but were proportionally more abundant at reef crest and flank compared with the reef base (Figure 5).

Visual comparisons of the size of surf clam (Spisula solidissima) shell fragments that make up the reef at different elevations were striking and led to a characterization of the reef substrate in July 2000 . From each $0.25 \mathrm{~m}^{2}$ quadrate sample, 50 shell fragments were selected at random and the largest dimension of each measured to the nearest millimeter. The size of clam shell fragments reflected the distribution of larger oysters (> $30 \mathrm{~mm}$ ) and varied among elevation strata (ANOVA, $\mathrm{p}<0.001$ ). Fragments of clam shell were significantly larger at reef base compared with flank and crest. Shell fragments from the flank and crest did not differ significantly (Figure 6).

Perkinsus marinus infections were found in $20 \%$ of the oysters examined from the Goodwin Island reef. Infections ranged from light to rare with an observed weighted prevalence of 0.32. Haplosporidium nelsoni infections ranged from rare to heavy and occurred in $24 \%$ of the oysters examined with an observed weighted prevalence of 0.48 . Infections

The mean density $(\ln (x+1)$ transformed) of oysters at Fisherman's Island varied significantly according to Reef Elevation, Substrate Type, and Date (Table 2). There was also a significant Reef Elevation by Substrate Type by Date interaction. This interaction effect was due to higher densities of oysters at Mean Low Water than at Subtidal elevations of the clam and oyster shell substrates each year except in 1999 when Subtidal oyster densities were greater than densities at Mean Low Water on clam shell reefs (Figure 7, Table 2). Densities of oysters increased over time at the subtidal elevation of the oyster shell reefs and at the Mean Low Water elevation of the clam shell reefs. This pattern was not evident at the Mean Low Water elevation on the oyster shell reef where the density of oysters was lowest in 1998. Oyster densities remained low throughout the study at the clam shell reefs' Subtidal elevation (Figure 7). None of the first order interaction effects were significant (all $\mathrm{p}>0.079$ ). Oysters were consistently more abundant on the oyster shell than on the clam shell reef habitat. Over-all abundance patterns on clam shell were similar to that found on the clam shell reef at Goodwin Island with a population dominated by small oysters and few oysters surviving to attain larger 
sizes (> $30 \mathrm{~mm}$ ) (Figure 8). By May 1997, nearly one year after reef construction, oysters were notably more abundant on the oyster shell reef compared with the clam shell reef. By May 1998 and through 1999, the size distribution of oysters on the oyster shell reef was bimodal with relatively large numbers of larger live oysters, whereas a unimodal size distribution of small live oysters was found on clam shell. Recently dead oysters with articulated shells were present on both reef types all years and tended to reflect the distribution of live oysters. There appeared to be increased survival on the oyster shell habitats as the ratio of live oyster to recently dead oyster abundance was greater on the oyster shell reefs than on the clam shell reefs each year. Because of the marked difference in oyster abundance and survival between the alternative substrate and oyster shell reefs, the clam shell and coal ash reefs were capped in Summer 1999 with a veneer of oyster shell. 


\section{DISCUSSION}

As oyster reef restoration efforts become more widespread along the Atlantic coast, we learn that there is no generic model for reef construction configuration (e.g., size, shape, vertical relief, substrate type) and elements of reef restoration are not universal such that a single formula should not be applied to reef design in every system. Patterns observed in adult populations of sessile marine invertebrate must be some function of larval supply and recruitment success (Grosburg 1982) but postsettlement survival is determined by an interplay of physical and biological selective processes, which act to modify the initial settlement distribution and may be quite different depending the characteristics of a specific system. What characteristics work for establishing and sustaining an oyster population in one system may not be as successful in another because these physical and biological factors that influence oyster population patterns may differ depending on the location of the reef. Constructed reef design should account for local geophysical (e.g., hypoxia, siltation, ice scour) and biological (e.g., aquatic and avian predators) conditions to provide shelter for oysters and associated fauna from such stressors. We suggest that factors related the availability of interstitial space and settlement habitat account for the observed differences in oyster abundance across the reef systems.

The ultimate goal of substrate placement in reef restoration efforts is the eventual formation of a self-renewing veneer of generations of living oysters encrusting the core base material. The formation of this living covering is dependent on the overall quality of the substrate for initial oyster survival. The choice of an appropriate substrate type for use as a reef base could dictate success or failure of the development of reef assemblage, depending on local conditions. The substrate should provide ample convolutions and surface area to afford settlement surface and refuge for young oysters from predation ahd physical stress. On intertidal reefs in Piankatank River, Virginia, Bartol and co-workers (Bartol \& Mann 1997; Bartol et al. 1999) determined that oyster survival is enhanced below the surface of the reef within the reef interstices. The nature of the reef substrate material affects the character and availability of these interior spaces and subsequently the overall quality of the habitat for oyster survival. Small fragments of Spisula solidissima shell are nearly flat and become tightly packed in aggregation. Larger shell 
fragments retain more three-dimensional curvature of the intact valve and when amassed into piles, afford more loft and void spaces within the substrate. The size of individual shell fragments varied with elevation on the subtidal mound at Goodwin Island and the distribution of oysters on the reef was reflective of this pattern. Oysters were more abundant and reached larger size classes when associated with larger shell fragments around the base of the reef. Although not measured directly, we observed no obvious spatial distribution pattern in the size of shell fragments on the clam shell reefs at Fisherman's Island and the shell fragments were uniformly small and comparable in size to the fragments found on the crest and flank regions of the Goodwin Island reef.

Differential survival of oysters on substrates of varying quality (and thus position on the reef at Goodwin Island) is a likely explanation for the abundance patterns we observed. Although this study was not designed to look at settlement and early postsettlement mortality directly, we observed that young oysters recruited to each location on the reef but did not persist equally through subsequent monitoring periods. We would expect that early post settlement densities were comparable across each reef strata at Goodwin Island and across reef type at Fisherman's Island, but we lack confirming data. The oyster populations on the clam shell mounds at Fisherman's Island and on the flank and crest of the Goodwin Island mound were numerically dominated with small, newlyrecruited individuals. Oysters at these locations never attained shell heights greater than $60 \mathrm{~mm}$ in any of the years sampled and proportionately few (between 0 and 25 oysters $/ \mathrm{m}^{2}$ at the Fisherman's Island clam shell mounds, 5 and 18 oysters $/ \mathrm{m}^{2}$ at the Goodwin Island reef flank, and 2 and 4 oysters $/ \mathrm{m}^{2}$ at the Goodwin Island reef crest) reached shell heights above $30 \mathrm{~mm}$ (Figures 4 and 8). While the oyster populations at the base of the Goodwin Island reef and on the oyster shell mounds at Fisherman's Island were also dominated by small individuals, overall densities of oysters were greater and large (older) oysters representing multiple year classes were present in the population. By May 1999, 8\% $\left(110\right.$ oysters $\left./ \mathrm{m}^{2}\right)$ of the standing stock at the oyster shell reefs Fisherman's Island had attained a shell height of $\geq 60 \mathrm{~mm}$ and $50 \%\left(680\right.$ oysters $\left./ \mathrm{m}^{2}\right)$ of the standing stock had grown to $\geq 30 \mathrm{~mm}$ shell height. Since large oysters generally produce more eggs than do smaller oysters (Davis and Chanley 1956, Cox and Mann 1992) and oysters can reach sexual maturity at shell heights smaller than $35 \mathrm{~mm}$ (Andrews 1979), this proportion of 
the standing stock represents a considerable number of oysters that could contribute to future reproductive events to sustain these reefs.

The reef bases at Goodwin Island and Fisherman's Island developed quite different oyster populations on similar substrate materials under different physical regimes and recruitment levels. Oyster recruitment at Fisherman's Island has been monitored during the reproductive season since 1995 (Morales-Alamo and Mann 1996) and has shown annual fluctuations in recruitment magnitude. Oyster settlement on the Eastern Shore is generally much greater than that of the western tributaries. Oyster recruitment was very low in 1996 and relatively high in 1997 and 1999 (Southworth et al. 2000; this study). Oyster densities on both substrate types showed a steady increase over time at Fisherman's Island but the population on the oyster shell far exceeded that on the clam shell mound. By 1999, the single oyster shells that make up the base of the reef were encrusted by a continuous living veneer of live oysters. The clam shell changed very little in appearance over the three years of monitoring and in 1999, looked very much the same as it did when the mound was built in 1996 - a mound of crushed clam shell bleached white in color with an underdeveloped epifaunal community.

Although the York River has been characterized by low recruitment in recent years (Morales-Alamo 1996, 1997, 1998; Southworth et al. 1999, 2000, 2001), juvenile oysters recruited to the Goodwin Island reef each year. Spawning of Crassostrea virginica is initiated by temperature (20-25 C) (Galtsoff 1964) or salinity cues (>10 psu) (Abbe 1986) and typically occurs between June and October in lower Chesapeake Bay (Andrews 1951). The relatively high number of recruits we observed in 1999 at the Goodwin Island reef compared with subsequent years is likely due to temporal differences in sampling events. In 1999, the reef was sampled in November, after the conclusion of the settlement period so the population reported here are inclusive of young oysters recruited to the reef during the summer of 1999. During the other two years, the reef was sampled in the summer at the beginning of reproductive activity and our data reflect the oysters that survived through the previous winter as well as some of the early recruits of that year. A recruitment event of the magnitude observed in November 1999 was not observed again in 2000 or 2001 , nor was it reflected in the number of small oysters observed in subsequent years. 
Decapod predators, including the blue crab, Callinectes sapidus, and Panopeid mud crabs (i.e., Panopeus herbstii, Dyspanopeus herbstii, Eurypanopeus depressus) are responsible for significant mortality in natural populations along the Atlantic Coast of the United States (Bisker and Castagna 1987; reviewed by White and Wilson 1996). Fragile shells of young oysters ( $<15 \mathrm{~mm}$ shell height) are susceptible crushing by these predators. Crabs generally chip the margins of the valve of larger oysters with their chelae to gain access to the tissue inside. Areas on the reef where the substrate consists of small, tightly packed shell fragments leave young oysters that settle on these areas of the reef vulnerable to crab predation. Substrate material with ample convolutions and interior surfaces for settlement out of direct reach of decapod predators gives young oysters a survival advantage not afforded to those that settled on less suitable substrates. A greater proportion of young oysters ( $\leq 30 \mathrm{~mm}$ shell height) showed evidence of decapod predation on the crest and flank of the reef compared with those collected from the base and the distribution of oysters with evidence of crab predation is reflective of the size distribution of clam shell fragments on the reef mound (Figures 5 and 6).

Proportionately fewer dead oysters collected from the base of the reef showed evidence of crab predation and it is likely that these oysters succumbed to other sources of mortality, such as disease and flat worm predation. Since a large proportion of the oysters collected in 1999 from the Goodwin Island reef mound were unaccounted for in 2000 , it is likely that many of the young oysters from 1999 were crushed when preyed upon by crabs and were not represented in our samples. We suspect that in areas where the substrate did not offer adequate shelter from predation, oyster mortality likely occurred due to decapod predation before infection could kill the oyster. Where the substrate afforded adequate refuge for young oysters from predators, oysters survived to attain larger sizes with a greater percentage of the mortality attributed to parasitic infections. We propose that early post-settlement mortality due to a combination of predation and disease is structuring the oyster community on this habitat.

Our findings serve to highlight the importance of the use of materials that provide adequate small-scale structural complexity when constructing oyster reefs, whether subtidally or intertidally. We have observed an interaction between the substrate material used in the construction of oyster reef habitats and the recruitment and survival of oysters 
on these habitats. Results from this study suggest that the interstitial space afforded by the material used to construct the reef contributes to the ability of oysters escape predation and survive. Oyster shell and large fragments of clam shell provided sufficient habitat to support and sustain a viable oyster population. The provision of large-scale vertical relief extending up in to the intertidal may not be as important in shallow $(<2 \mathrm{~m})$, subtidal habitats with good water quality as is the provision of proper settlement substrate. We recommend that the results of our study be used to reevaluate the use of substandard reef configurations in oyster reef restoration efforts. Providing high relief mounds may not be as important as adequate surface heterogeneity in sustaining oyster populations in systems where sedimentation and water quality are not deleterious to the reef and oysters upon it. We recommend that the results of our study be used to reevaluate the use of substandard reef configurations and to implement a wise use of the oyster shell resource in future oyster reef restoration efforts. 


\section{LITERATURE CITED}

Abbe, G. R. 1986. A review of some factors that limit oyster recruitment in Chesapeake Bay. Amer. Malac. Bull. 3: 59-70.

Andrews, J. D. 1951. Seasonal patterns of oyster settling in the James River and Chesapeake Bay. Eçology 32: 752-758.

Andrews, J. D. 1979. Pelecypoda: Ostreidae. Pages 293-341 in A. C. Giese and J. S. Pearse (eds.). Reproduction in Marine Invertebrates, Volume V. Molluscs:

Pelecypods and Lesser Classes. Academic Press, New York.

Bahr, L. M. 1974. Aspects of the structure and function of the intertidal oyster reef community in Georgia. Ph. D. Dissertation, University of Georgia. 149 pp.

Bartol, I. \& R. Mann. 1999. Small-scale patterns of recruitment on a constructed intertidal reef: The role of spatial refugia. pp. 159-170 In M. W. Luckenbach, R. Mann, \& J. Wesson (eds.). Oyster Reef Habitat Restoration: A Synopsis and Synthesis of Approaches. Virginia Institute of Marine Science, Gloucester Point, Virginia.

Bartol, I., R. Mann, M. Luckenbach. 1999. Growth and mortality of oysters (Crassostrea virginica) on constructed intertidal reefs: effects of tidal height and substrate level. $J$. Exp. Mar. Biol. Ecol. 237:157-184.

Bisker, R. \& M. Castagna. 1987. Predation on single spat oysters, Crassostrea virginica Gmelin by blue crabs, Callinectes sapidus Rathburn and mud crabs, Panopeus herbstii Milne-Edwards. J. Shellfish. Res. 6: 37-40.

Brumbaugh, R. D., L .A. Sorabella, C. Oliveras Garcia, W. J. Goldsborough \& J. A. Wesson. 2000. Making a case for community-based oyster restoration: An example from Hampton Roads, Virginia, USA. J. Shellfish Res. 19: 467-472.

Burreson, E.M., E. Robinson \& A. Villaba. 1988. A comparison of paraffin histology and hemolymph analysis for the diagnosis of Haplosporidium nelsoni (MSX) in Crassostrea virginica (Gmelin). J. Shellfish Res. 7: 19-23.

Cox, C. \& R. Mann. 1992. Temporal and spatial changes in fecundity of Eastern oysters, Crassostrea virginica (Gmelin, 1791) in the James River, Virginia. ). J. Shellfish Res. 11: 49-54.

Dame, R. F. 1979. The abundance, diversity and biomass of macrobenthos on North Inlet, South Carolina, intertidal oyster reefs. Proc. Natl. Shellfish. Assoc. 68:6-10

Davis, H. C. \& P. E. Chanley. 1956. Spawning and egg production of oysters and clams. Proc. Nat. Shellfish. Assoc. 46: 40-51. 
Diaz, R. J., R. J. Neubauer, L. C. Schaffner, L. Pihl \& S. P. Baden. 1992. Continuous monitoring of dissolved oxygen in an estuary experiencing periodic hypoxia and the effect of hypoxia on macrobenthos and fish. Science of the Total Environment, Supplement 1992. 1055-1068.

Galtsoff, P. S. 1964. The American Oyster Crassostrea virginica Gmelin. Fish. Bull. 64: $1-480$.

Gregg, J. H. 1948. Replication of substrate detail by barnacles and some other marine organisms. Biol. Bull. 94: 161-168.

Grosburg, R. K. 1982. Intertidal zonation of barnacles: The influence of planktonic zonation of larvae on the vertical distribution of adults. Ecology 63: 894-899.

Gunter, G. \& W. D. Burke. 1978. Further notes on how oysters land when planted. Proc. Natl. Shellfish. Assoc. 68: 1-4.

Haas, L. W. 1977. The effect of the spring-neap tidal cycle on the vertical salinity structure of the James, York, and Rappahannock Rivers, Virginia, U.S.A. Estuarine and Coastal Marine Science 5: 485-496.

Hargis, W. J. 1999. The evolution of the Chesapeake oyster reef system during the Holocene Epoch. pp 5-23 In M. W. Luckenbach, R. Mann, \& J. Wesson (eds.). Oyster Reef Habitat Restoration: A Synopsis and Synthesis of Approaches. Virginia Institute of Marine Science, Gloucester Point, Virginia.

Kennedy, V. S. \& L. P. Sanford. 1999. Characteristics of relatively unexploited beds of the Eastern Oyster, Crassostrea virginica, and early restoration programs. pp 25-46 In M. W. Luckenbach, R. Mann, \& J. Wesson (eds.). Oyster Reef Habitat Restoration: A Synopsis and Synthesis of Approaches. Virginia Institute of Marine Science, Gloucester Point, Virginia.

Lenihan, H. S. 1999. Physical-biological coupling on oyster reefs: How habitat structure influences individual performance. Ecol. Monogr. 69: 251-275.

Lenihan, H. S., F. Michelli, S. W. Shelton \& C. H. Peterson. 1999. The influence of multiple environmental stressors on susceptibility to parasites: An experimental determination with oysters. Limnol. Oceanogr. 44(3, part 2): 910-924.

Lenihan, H. S. \& C. H. Peterson. 1998. How habitat degradation through fishery disturbance enhances impacts of bottom water hypoxia on oyster reefs. Ecol. Appl. 8:128-142.

MacKenzie, C. L. 1996. History of oystering in the United States and Canada, featuring the eight greatest oyster estuaries. Marine Fisheries Review 58:1-78 
Mackin, J.G. 1962. Oyster disease caused by Dermocystidium marinum and other microorganisms in Louisiana. Publ. Inst. Mar. Sci., Univ. Texas. 7: 132-229.

Mann, R. 2000. Restoring the oyster reef communities in the Chesapeake Bay: A commentary. J. Shellfish Res. 19: 335-339.

Meisner, B. 1995. Goodwin Island reserve is site of new oyster reef. A Fair Bay, Newsletter for Friends of the Chesapeake Bay National Estuarine Research Reserve in Virginia, 4(3,4): 1-2.

Morales-Alamo, R. and R. Mann. 1996. The status of Virginia's public oyster fishery 1995. Marine Resource Special Report. Virginia Institute of Marine Science, Gloucester Point, Virginia. 42 p.

Morales-Alamo, R. and R. Mann. 1997. The status of Virginia's public oyster resource 1996. Virginia Marine Resource Report 97-5. Virginia Institute of Marine Science, Gloucester Point, Virginia. 46 p.

Morales-Alamo, R. and R. Mann. 1998. The status of Virginia's public oyster resource 1997. Virginia Marine Resource Report 98-2. Virginia Institute of Marine Science, Gloucester Point, Virginia. 49 p.

O'Beirn, F. X., M. W. Luckenbach, J. A. Nestlerode \& G. M. Coates. 2000. Toward design criteria in constructed oyster reefs: Oyster recruitment as a function of substrate type and tidal height. J. Shellfish Res. 19: 387-395.

Ragone Calvo, L. M. \& E. M. Burreson. 2000. The status of the major oyster diseases in Virginia 1999. Marine Resource Special Report. Virginia Institute of Marine Science, Gloucester Point, Virginia. 23 p.

Ragone Calvo, L. M. \& E. M. Burreson. 2001. The status of the major oyster diseases in Virginia 2000. Marine Resource Special Report. Virginia Institute of Marine Science, Gloucester Point, Virginia..

Ray, S. M. 1952. A culture technique for the diagnosis of infections with Dermocystidium marinum, Mackin, Owen, and Collier, in oysters. Science 116: 360361.

Southworth ,M, R. Mann. 1998. Oyster reef broodstock enhancement in the Great Wicomico River, Virginia. J. Shellfish Res. 17: 1101-1114.

Southworth, M.J., J.M. Harding, and R. Mann. 1999. The status of Virginia's public oyster resource 1998. Virginia Marine Resource Report 99-6. Virginia Institute of Marine Science, Gloucester Point, Virginia. 37 p. 
Southworth, M.J., J.M. Harding, and R. Mann. 2000. The status of Virginia's public oyster resource 1999. Virginia Marine Resource Report 2000-03. Virginia Institute of Marine Science, Gloucester Point, Virginia. 38 p.

Southworth, M.J., J.M. Harding, and R. Mann. 2001. The status of Virginia's public oyster resource 2000. Virginia Institute of Marine Science, Gloucester Point, Virginia. $56 \mathrm{p}$.

Underwood, A. J. 1997. Experiments in ecology: their logical design and interpretation using analysis of variance. Cambridge University Press, Cambridge, UK, 504 pp.

Volety, A. K., F. O. Perkins, R. Mann, P. R. Hershberg. 2000. Progression of diseases caused by the oyster parasites, Perkinsus marinus and Haplosporidium nelsoni, in Crassostrea virginica on constructed intertidal reefs. J. Shellfish Res. 17: 341-347.

Wells, H. W. 1961. The fauna of oyster beds, with special reference to the salinity factor. Ecol. Monogr. 31:239-266.

Wesson, J. R. Mann, M. Luckenbach. 1999. Oyster restoration efforts in Virginia. . pp 117-129 In M.W. Luckenbach, R. Mann, and J. Wesson (eds.). Oyster Reef Habitat Restoration: A Synopsis and Synthesis of Approaches. Virginia Institute of Marine Science, Gloucester Point, Virginia.

White, M. E. \& E. A. Wilson. 1996. Predators, pests, and competitors. Pp. 559-579 In V. S. Kennedy, R. I. E. Newell \& A. F. Eble (eds.) The Eastern Oyster Crassostrea virginica. Maryland Sea Grant College.

Zimmerman, R., T. J. Minello, T. Baumer, M. Castiglione. 1989. Oyster reef as a habitat for estuarine macrofauna. NOAA Technical Memorandum NMFS-SEFC-249 


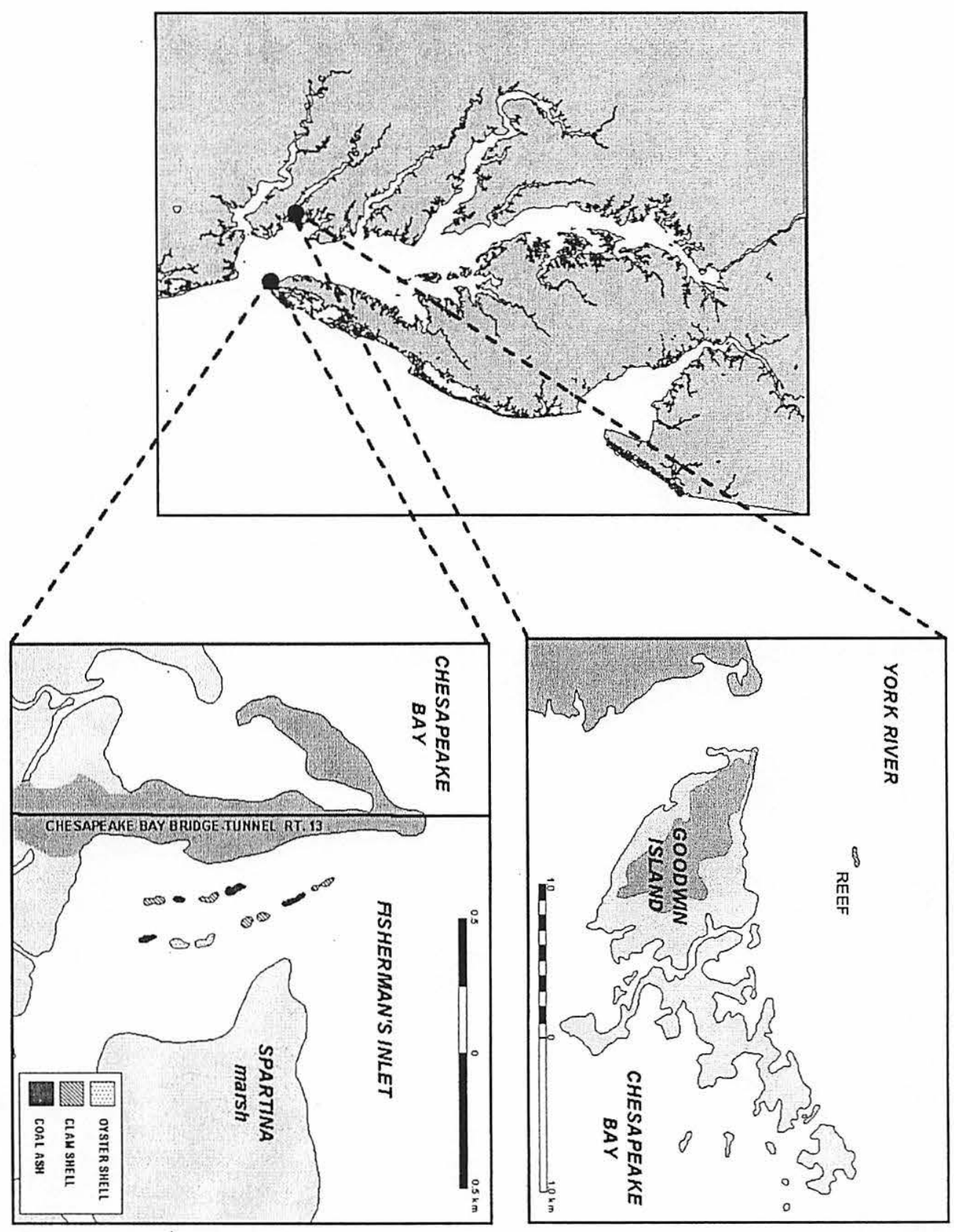

Figure 1: Location of created oyster reef study areas near Goodwin Island at the mouth of York River and near Fisherman's Island at the mouth of Chesapeake Bay. 


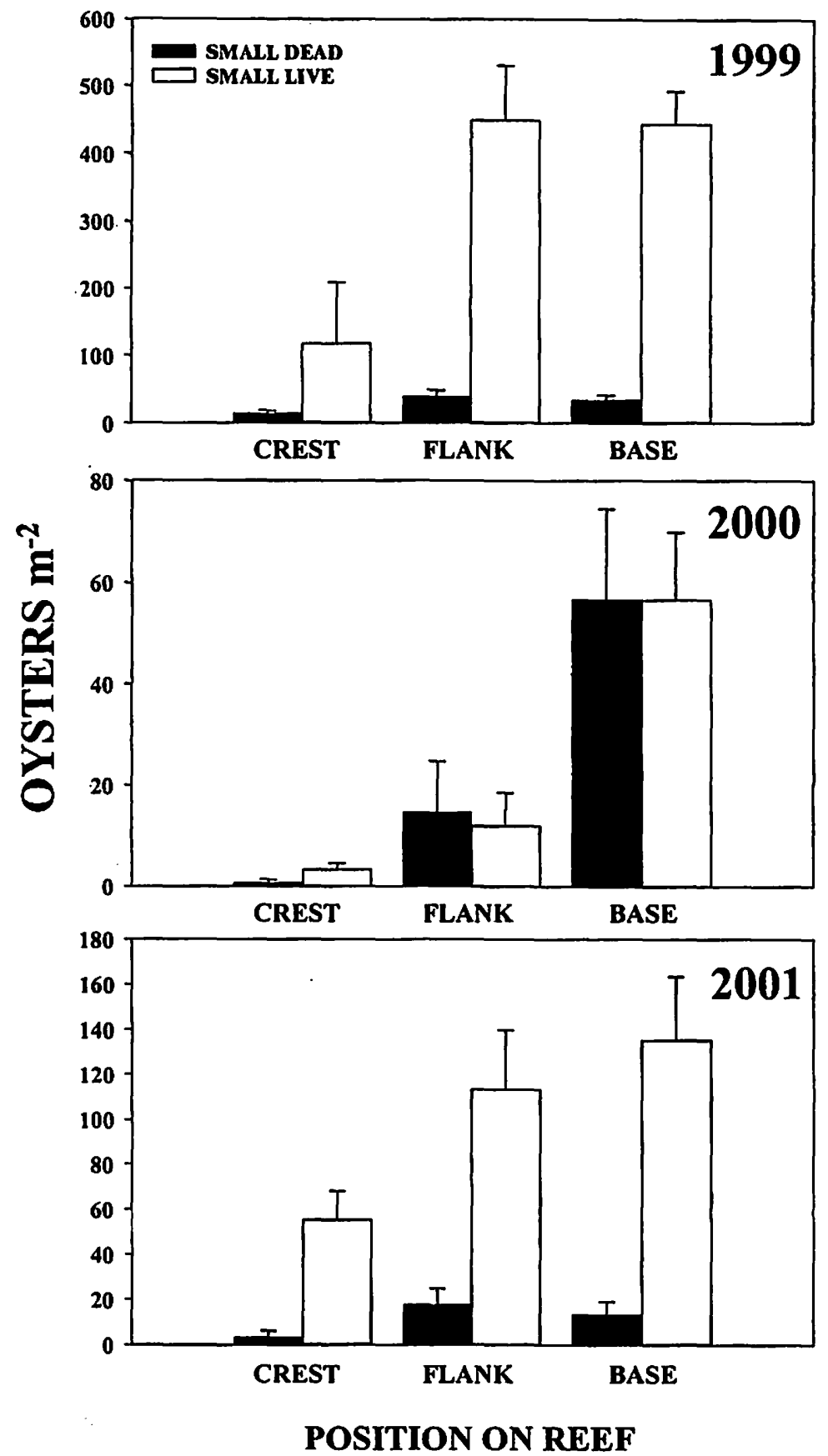

Figure 2: Mean density of small ( $\leq 30 \mathrm{~mm}$ shell height) live and dead oysters, Crassostrea virginica, at the Crest ( $1.5 \mathrm{~m}$ above the seabed), Flank ( $0.8 \mathrm{~m}$ above the seabed), and Base ( $0.2 \mathrm{~m}$ above the seabed) of the Goodwin Island created oyster reef, York River, Virginia, November 1999, July 2000, and June 2001. Bars represent mean abundance per square meter $+1 S E(n=6)$. 


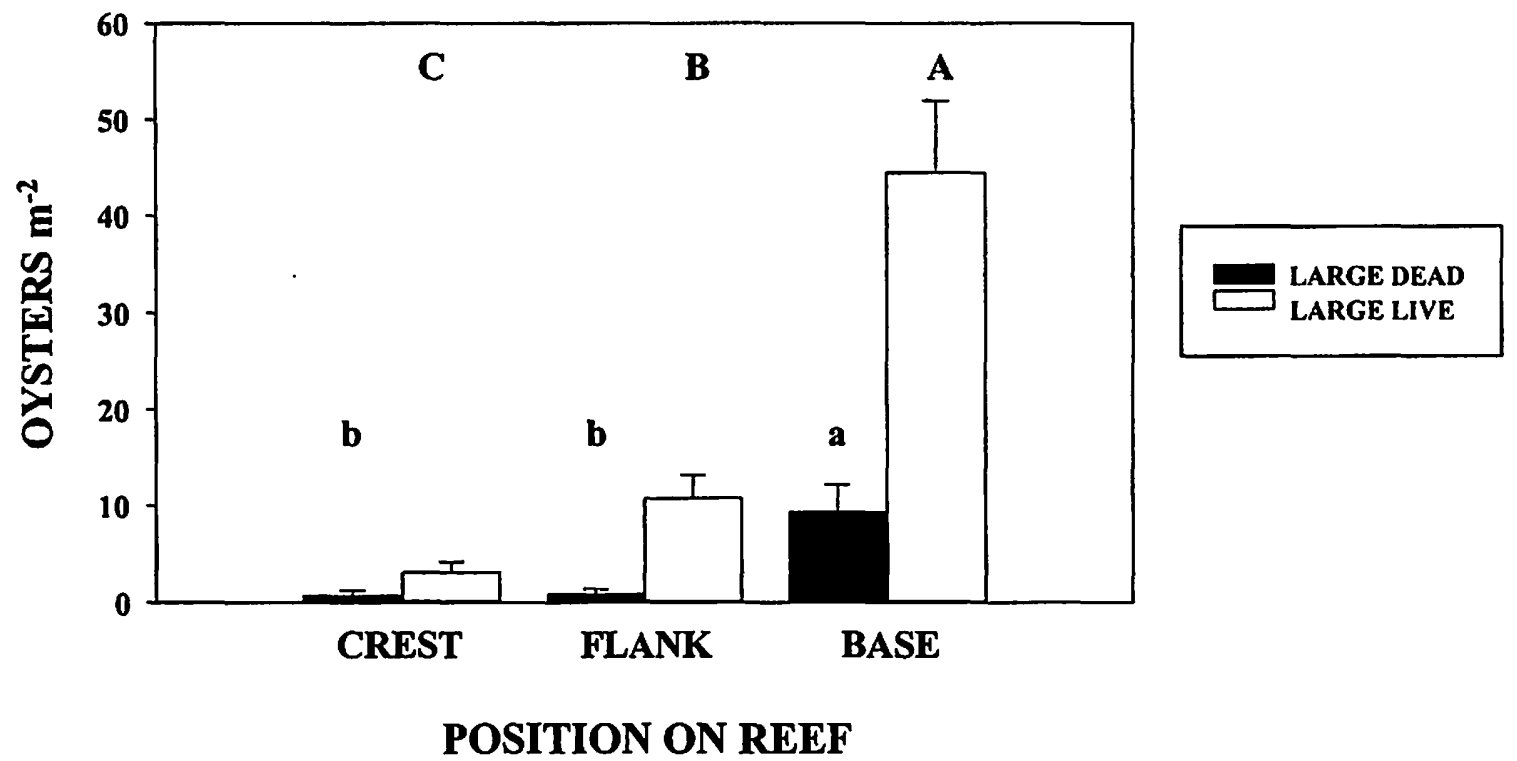

Figure 3: Mean density of large ( $>30 \mathrm{~mm}$ shell height) live and dead (non-fouled, articulated oyster shells only) oysters at the Crest ( $1.5 \mathrm{~m}$ above the seabed), Flank $(0.8 \mathrm{~m}$ above the seabed), and Base ( $0.2 \mathrm{~m}$ above the seabed) of the Goodwin Island created oyster reef, York River, Virginia in 1999, 2000, and 2001. Bars represent mean abundance per square meter $+1 \mathrm{SE}(n=6)$. Separate ANOVAs and SNK a posteriori tests were used to compare densities of live and dead oysters. As there was no significant effect of sampling date, data shown are pooled from all sampling events. Letters above bars represent results of SNK a posteriori comparisons: dead $-a>b$ and live $-\mathrm{A}>\mathrm{B}>\mathrm{C}$ at $\alpha=0.05$. 


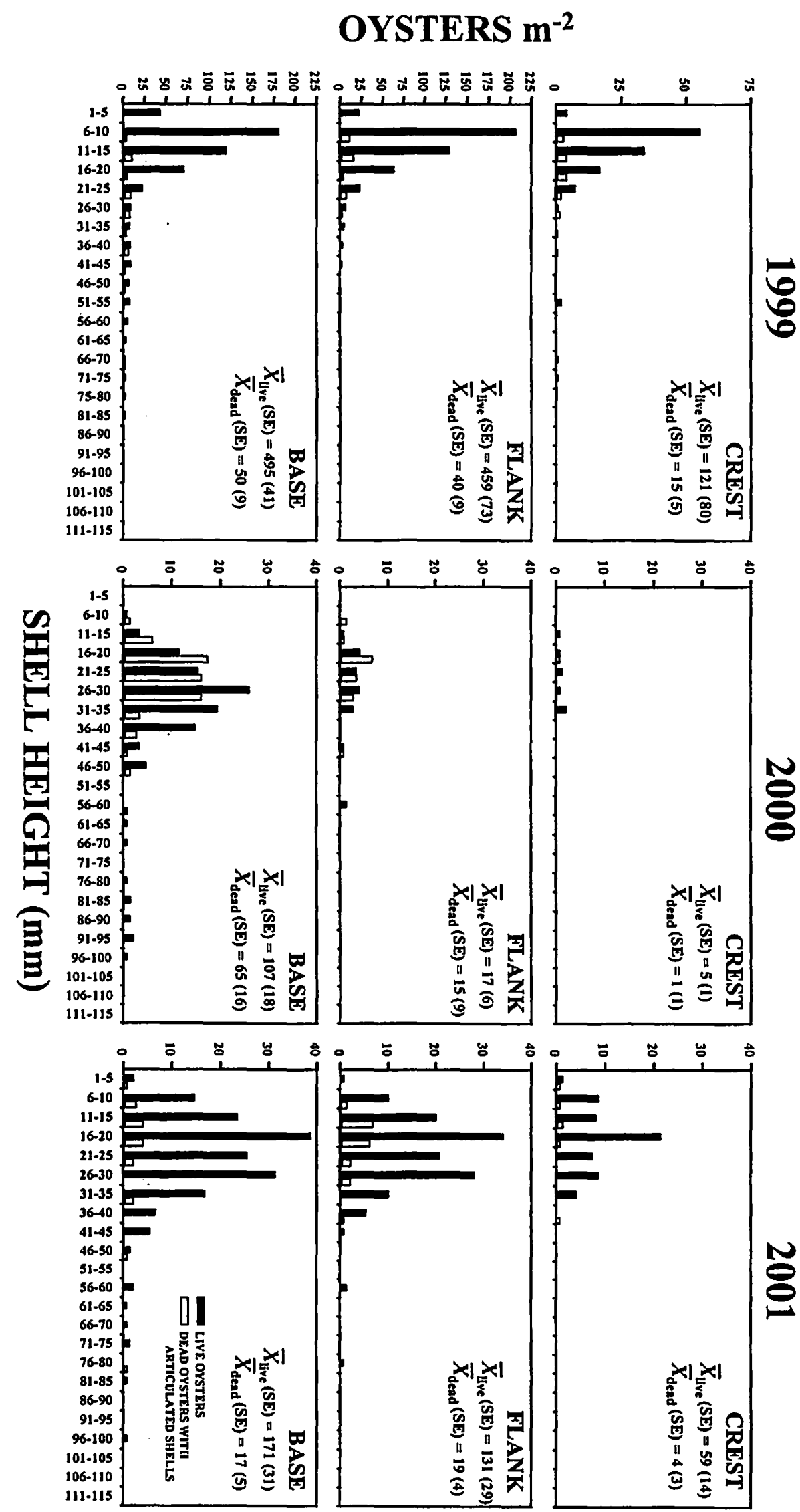

Figure 4: Size frequency distributions for live and dead (non-fouled, empty articulated oyster shells) oysters collected from the Crest, Flank, and Base of the Goodwin Island created oyster reef, November 1999, July 2000, and June 2001. Mean oyster densities for each size class were derived from six replicate $0.25 \mathrm{~m}^{2}$ quadrate samples collected from each reef elevation each sampling period. Omitted from this figure is one live oyster (shell height $=166 \mathrm{~mm}$ ) collected from the reef Base in July 2000. Note the order of magnitude difference in scale of abundance between 1999 and 2000/2001. 


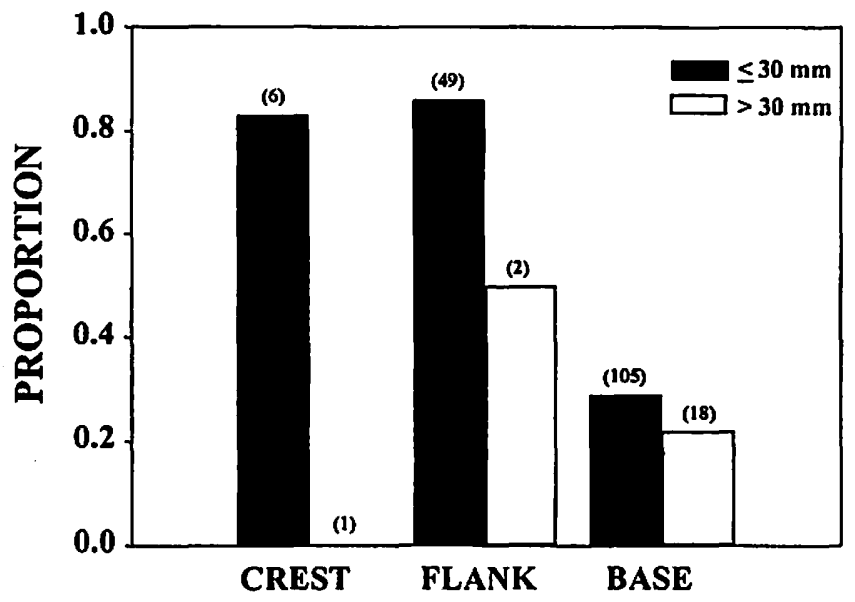

POSITION ON REEF

Figure 5: Proportion of dead oysters with evidence of predation by crabs out of total number of dead oysters sampled in 2000 and 2001 from each position on the reef. Predation by crabs was distinguished from other mortality sources by the presence of chipped or cracked valve margins, puncture holes within the umbo region, crushing of the umbo region, and complete crushing of the valves. Numbers in parentheses above bars corresponds to total number of individuals observed.

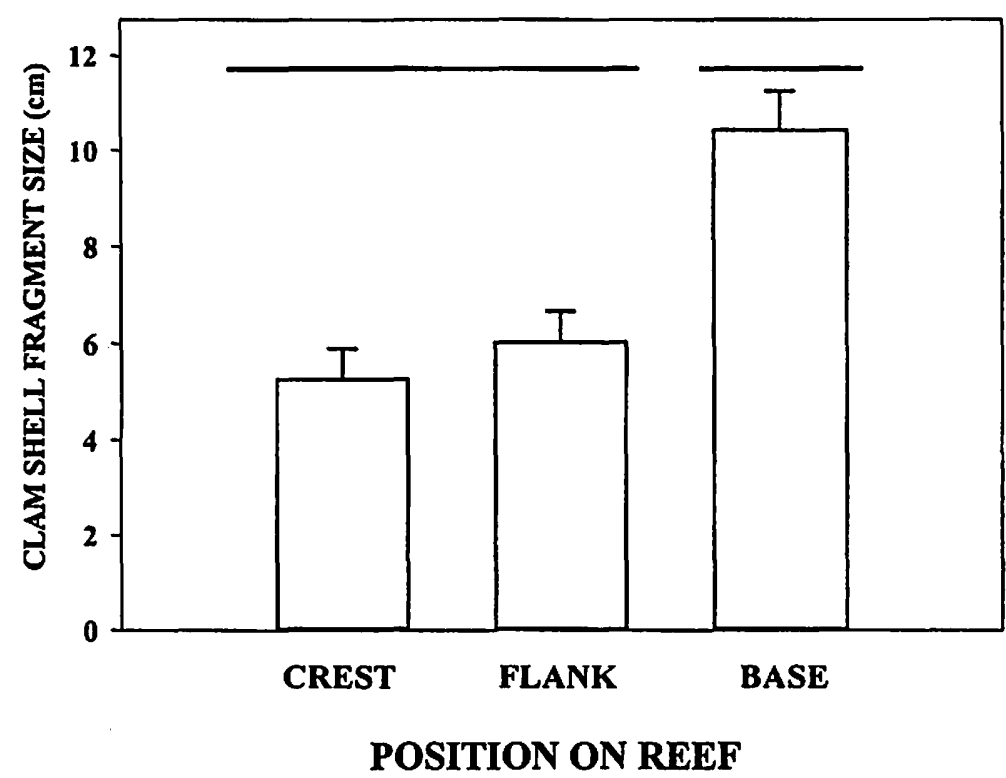

Figure 6: Patterns of surf clam shell (Spisula solidissima) fragments size distribution at each of three reef elevation strata - Crest ( $1.5 \mathrm{~m}$ above the seabed), Flank $(0.8 \mathrm{~m}$ above the seabed), and Base ( $0.2 \mathrm{~m}$ above the seabed) on the Goodwin Island created oyster reef. Bars represent means $+1 \mathrm{SE}(\mathrm{n}=6)$. Bars underlying the same line are not significantly different at $\alpha=0.05$ (Tukey test). 


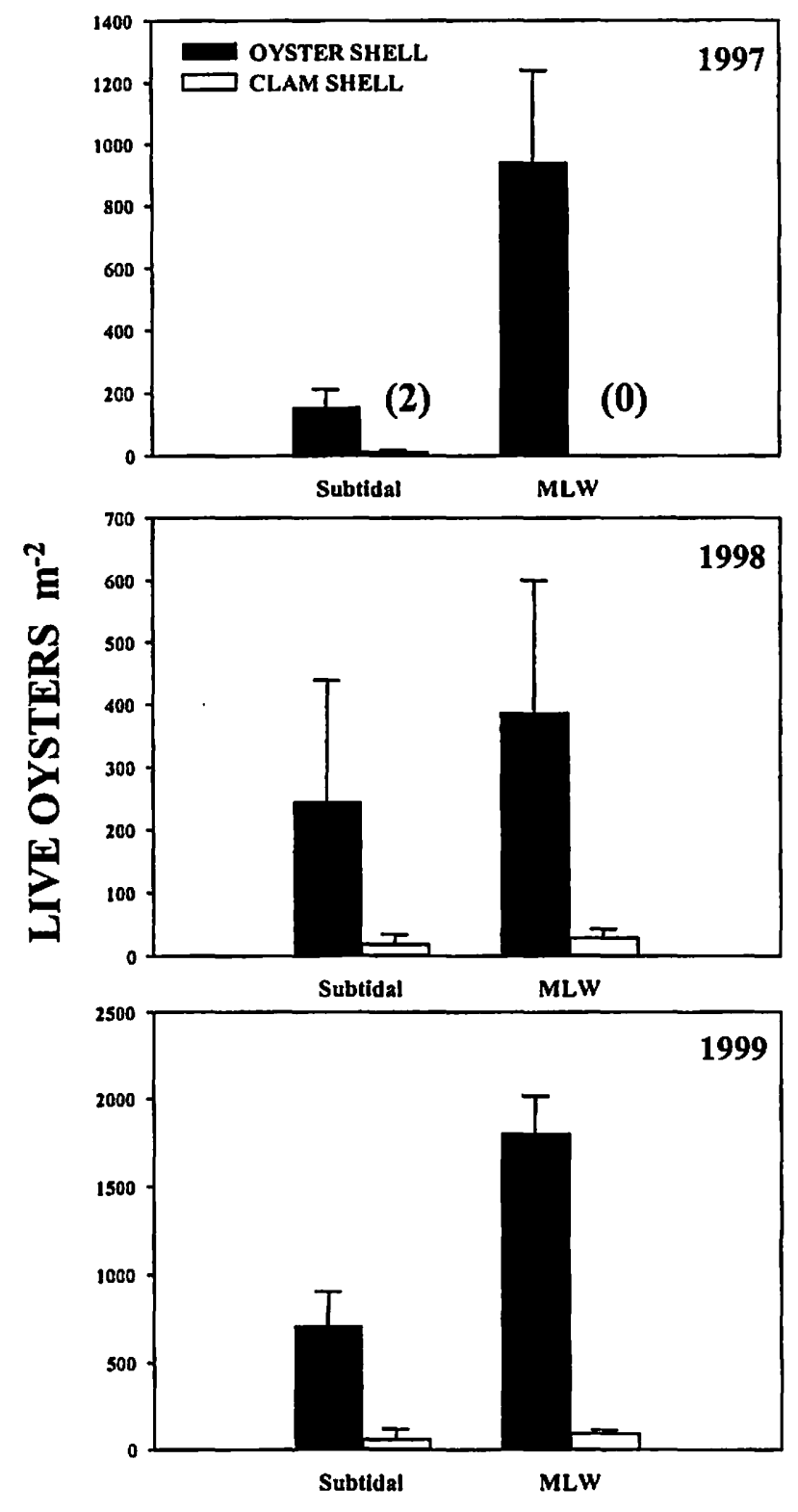

TIDAL HEIGHT

Figure 7: Mean density of live oysters at Subtidal and Mean Low Water elevations on constructed oyster shell and clam shell intertidal reefs at Fisherman's Island, Virginia over three years. Bars represent means + $1 \mathrm{SE}$ $(n=6)$. Numbers in parentheses in the top panel represent mean oyster abundance on clam shell substrate. 


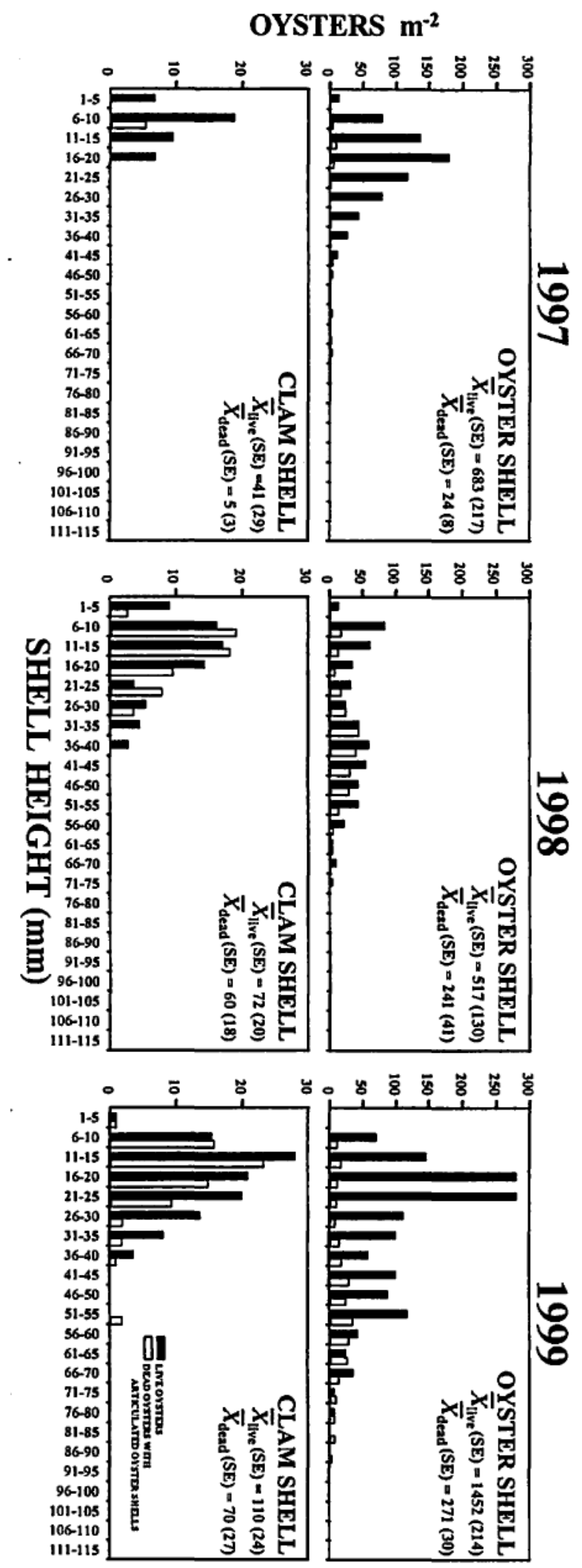

Figure 8: Size frequency distributions for live and dead (non-fouled, empty articulated oyster shells) oysters collected from oyster shell and clam shell reef mounds at Fisherman's Island, Virginia in May 1997, 1998, and 1999. Bars represent mean oyster densities for each size class and are for all animal combined from three replicate quadrate samples $\left(0.0625 \mathrm{~m}^{2}\right)$ collected from each of two clam shell reefs and one oyster shell reef at three tidal heights $(0.25 \mathrm{~m}$ below mean low water; at mean low water; and $0.25 \mathrm{~m}$ above mean low water) and one oyster reef at two tidal heights $(0.25 \mathrm{~m}$ below mean low water and at mean low water). Because of settling and erosion of the reefs over time (in particular, one of the oyster shell reefs), we were unable to sample the higher tidal heights from all reefs during the entire study and were left with an unbalanced sampling design. 
Table 1 (a): Summary of ANOVAs testing whether oyster densities $(\ln (\mathrm{x}+1)$ transformed) at the Goodwin Island's constructed oyster reef varied as a function of position on reef (Crest (C), Flank (F), or Base(B)), date, and their interactions. Multiple comparisons of the means were analyzed using Student-Newman-Keuls tests. Treatments are listed in ascending order of means and treatments not connected by a common underline differed at $\mathrm{p}=0.05$.

\begin{tabular}{|c|c|c|c|c|c|c|c|}
\hline & Source & df & Sum-of-Squares & Mean Square & $F$-value & $P$-value & $\begin{array}{c}\text { Multiple } \\
\text { Comparisons }\end{array}$ \\
\hline \multirow{4}{*}{$\begin{array}{l}\text { Small dead oysters } \\
(\leq 30 \mathrm{~mm})\end{array}$} & position on reef & 2 & 38.81 & 19.40 & 15.19 & $<0.001$ & $\underline{\mathrm{C}}<\underline{\mathrm{F}=\mathrm{B}}$ \\
\hline & date & 2 & 17.92 & 8.96 & 7.02 & 0.002 & $' 99<<^{\prime} 00={ }^{\prime} 01$ \\
\hline & position on reef $x$ date & 4 & 12.74 & 3.18 & 2.49 & 0.056 & \\
\hline & error & 45 & 57.47 & 1.28 & & & \\
\hline \multirow{4}{*}{$\begin{array}{l}\text { Large dead oysters } \\
(>30 \mathrm{~mm})\end{array}$} & position on reef & 2 & 26.405 & 13.203 & 17.54 & $<0.001$ & $\mathrm{C}=\mathrm{F}<\mathrm{B}$ \\
\hline & date & 2 & 1.994 & 0.972 & 1.29 & 0.285 & \\
\hline & position on reef $x$ date & 4 & 2.107 & 0.527 & 0.70 & 0.596 & \\
\hline & error & 45 & 33.871 & 0.753 & & & \\
\hline \multirow{4}{*}{$\begin{array}{l}\text { Small live oysters } \\
(\leq 30 \mathrm{~mm})\end{array}$} & position on reef & 2 & 35.579 & 17.790 & 30.42 & $<0.001$ & \\
\hline & date & 2 & 78.847 & 39.423 & 67.42 & $<0.001$ & \\
\hline & position on reef $x$ date & 4 & 9.418 & 2.354 & 4.03 & 0.007 & see Table $1 b$ \\
\hline & error & 45 & 26.313 & 0.585 & & & \\
\hline \multirow{4}{*}{$\begin{array}{l}\text { Large live oysters } \\
(>30 \mathrm{~mm})\end{array}$} & position on reef & 2 & 62.04 & 31.02 & 26.97 & $<0.001$ & $\underline{\mathrm{C}}<\mathrm{F}<\mathrm{B}$ \\
\hline & date & 2 & 3.24 & 1.62 & 1.41 & 0.256 & \\
\hline & position on reef $\mathrm{x}$ date & 4 & 3.72 & 0.93 & 0.81 & 0.527 & \\
\hline & error & 45 & 51.76 & 1.15 & & & \\
\hline
\end{tabular}


Table 1 (b): Results of Student-Newman-Keuls multiple comparison tests on mean small live oysters $(\leq 30$ $\mathrm{mm}$ shell height) densities. Treatments not connected by a common underline differed at $\mathrm{p}=0.05$.

Effect of position on reef for each year:

\begin{tabular}{ccc}
1999 & 2000 & 2001 \\
$\mathbf{C}<\mathbf{F}=\mathbf{B}$ & $\underline{\mathbf{C}}<\mathbf{F}=\mathbf{B}$ & $\mathbf{C}=\mathbf{F}=\mathbf{B}$ \\
\hline
\end{tabular}

Effect of year at each position on reef:

$\mathrm{HIGH}$

$\underline{00}<' \underline{99=} 01$
MIDDLE

$\underline{00}<\underline{01}<\underline{\prime 99}$
LOW

$\underline{00}<’ 01<999$

Table 2: Summary of ANOVA of live oyster densities $(\ln (x+1)$ transformed) from the reefs at Fisherman's Island, Virginia.

$\begin{array}{llllll}\text { Source } & \text { df } & \begin{array}{l}\text { Sum-of- } \\ \text { Squares }\end{array} & \begin{array}{l}\text { Mean } \\ \text { Square }\end{array} & \text { F-value } & \text { P-value } \\ \text { elevation } & 1 & 17.381 & 17.381 & 8.97 & \mathbf{0 . 0 0 4} \\ \text { substrate type } & 1 & 318.188 & 318.188 & 164.29 & <0.001 \\ \text { elevation x substrate type } & 1 & 1.290 & 1.290 & 0.67 & 0.418 \\ \text { date } & 2 & 40.712 & 20.356 & 10.51 & <0.001 \\ \text { elevation x date } & 2 & 10.277 & 5.139 & 2.65 & 0.079 \\ \text { substrate type x date } & 2 & 2.582 & 1.291 & 0.67 & 0.517 \\ \text { elevation x substrate type x date } & 2 & 22.894 & 11.447 & 5.91 & \mathbf{0 . 0 0 5} \\ \text { error } & 60 & 116.203 & 1.937 & & \end{array}$




\section{ACKNOWLEDGEMENTS}

The authors wish to thank numerous individuals that helped in the field sampling, especially P. G. Ross, Kristen Delano, Elizabeth Hinchey, Scott Lerberg, and Bob Carroll. Juanita Walker analyzed oyster tissue samples for parasitic infection. This report will be submitted in manuscript form to the Journal of Shellfish Research for peer review. 